\title{
First report of Cryptosporidium viatorum and Cryptosporidium occultus in humans in China, and of the unique novel $C$. viatorum subtype XVaA3h
}

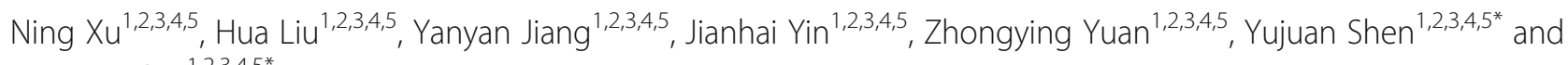
Jianping $\mathrm{CaO}^{1,2,3,4,5^{*}}$ (1)

\begin{abstract}
Background: Cryptosporidium is a genus of common intestinal protozoa, members of which cause diarrhea in a wide variety of hosts. Previous studies on Cryptosporidium in China have mainly focused on diarrhea sufferers, children, and immunodeficient individuals such as HIV/AIDS patients. However, the epidemiological characteristics of Cryptosporidium in the population in rural areas remain unclear. Herein, we investigated the prevalence of, and risk factors for, Cryptosporidium in rural areas of Binyang County, Guangxi Zhuang Autonomous Region, China, and genetically characterized the Cryptosporidium isolates we obtained.
\end{abstract}

Methods: From August to December 2016, two villages in Binyang County, Guangxi, were sampled using a random cluster sampling method. Fresh fecal samples were collected from all eligible residents (residence time $>6$ months). Molecular characterization of Cryptosporidium was carried out based on its SSU rRNA, gp60, actin and hsp70 gene sequences. Fisher's exact test were conducted to assess the risk factors for Cryptosporidium infection.

Results: A total of 400 fecal samples were collected from 195 males (48.8\%) and 205 females (51.2\%). Two samples (0.5\%) were positive for Cryptosporidium and were identified as C. viatorum and C. occultus respectively. Moreover, a new $C$. viatorum subtype XVaA3h was identified based on the sequence of the gp 60 gene.

Conclusions: To our knowledge, this is the first report of C. viatorum and C. occultus infections in humans in China and of $C$. viatorum subtype XVaA3h. The findings provide important information on the prevalence of Cryptosporidium in the Chinese population, and expand the range of Cryptosporidium species known to infect people in China.

Keywords: Cryptosporidium, Subtype, C. viatorum, C. occultus, Rural area

\section{Background}

Members of the Cryptosporidium genus of intestinal protozoa infect a wide range of hosts including humans, nonhuman primates, birds, amphibians, fish and reptiles [1]. Global concern was raised following an outbreak of cryptosporidiosis in Wisconsin, USA, in 1993, in which 403,000 individuals were affected and 100 fatalities were reported [2]. Only small quantities of oocysts are needed to establish infection, and once food or drinking water is contaminated

\footnotetext{
*Correspondence: amyshyj12@163.com; caojp@yahoo.com

${ }^{1}$ Key Laboratory of Parasite and Vector Biology, Ministry of Health, Shanghai 200025, China

Full list of author information is available at the end of the article
}

with Cryptosporidium oocysts, or humans come into contact infected individuals or animals, cryptosporidiosis outbreaks may occur [3]. Cluster outbreaks of cryptosporidiosis reported worldwide have represented a great threat to public health $[3,4]$. Symptoms of human cryptosporidiosis range from self-limiting diarrhea in (mainly) immunocompetent individuals, to persistent diarrhea (especially in children younger than 5-years-old). Cryptosporidiosis has been described as the second ranked causative agent of diarrhea in children in developing countries in southern Africa [5]. However, no effective drugs or vaccines have been developed, hence early detection and tracing the source of

(c) The Author(s). 2020 Open Access This article is distributed under the terms of the Creative Commons Attribution 4.0 International License (http://creativecommons.org/licenses/by/4.0/), which permits unrestricted use, distribution, and reproduction in any medium, provided you give appropriate credit to the original author(s) and the source, provide a link to the Creative Commons license, and indicate if changes were made. The Creative Commons Public Domain Dedication waiver (http://creativecommons.org/publicdomain/zero/1.0/) applies to the data made available in this article, unless otherwise stated. 
infection are of great importance for preventing outbreaks of cryptosporidiosis.

Globally, cryptosporidiosis is more endemic in developing countries than in developed countries [6]. In China, the reported human prevalence of Cryptosporidium has ranged from 0.0 to $16.5 \%$ since the first two cases were reported in Jiangsu Province in 1987, and a strong correlation was found between the infection and HIV/AIDS [7-12]. Moreover, Cryptosporidium was responsible for about 1.4 to $10.4 \%$ of diarrhea episodes in China [9].

To date, at least 39 species of Cryptosporidium have been identified [13-16], and at least 21 species are considered zoonotic, among which $C$. hominis and $C$. parvum are the two main pathogens causing cryptosporidiosis in humans [17]. However, in recent years, with the development of molecular biological technologies, the number of cryptosporidiosis cases confirmed to be caused by other Cryptosporidium species has increased, and some species or genotypes are predominant in specific countries or regions. For example, studies in Jiangsu and Shanghai, China, revealed unusually high prevalence of $C$. andersoni in diarrhea patients $[17,18]$. C. cuniculus, for which the natural host is rabbit, was found in patients with diarrhea in the UK [19], and C. xiaoi, mainly found in sheep and goat, was detected in HIV/AIDS sufferers with clinical manifestations including vomiting [20]. To our knowledge, seven species of Cryptosporidium-C. hominis, $C$. parvum, C. andersoni, C. meleagridis, C. felis, C. canis and C. suis have been identified in humans in China [1].

At present, cryptosporidiosis is not included in the National Disease Reporting System in China [21], and Cryptosporidium oocyst examination is not performed routinely on patients with diarrhea or other gastrointestinal symptoms, so the prevalence of Cryptosporidium in China may be underestimated. The present study aimed to investigate the prevalence, risk factors and species/genotype distribution of Cryptosporidium among a rural population in China, which are of great relevance to public health.

\section{Methods}

\section{Study area}

Guangxi is situated in southern China, between $22^{\circ} 54^{\prime}-$ $26^{\circ} 24^{\prime} \mathrm{N}$ and $104^{\circ} 26^{\prime}-112^{\circ} 04^{\prime} \mathrm{E}$. It borders the Beibu Gulf to the south, and is adjacent to Vietnam in the southwest. Binyang County, which belongs to Nanning City of Guangxi Zhuang Autonomous Region, is located in the south-central part of Guangxi and the northeast part of Nanning City. It is high-altitude in the south and low-altitude in the north, surrounded by earthy mountains to the east, south and west, with an open basin in the middle and a large alluvial plain. It has a subtropical monsoon climate with abundant light and heat, long summer and short winter, and abundant rainfall.

\section{Study design and population}

A cross-sectional survey was carried out to investigate the prevalence of, risk factors for, and species/genotype distribution of Cryptosporidium in a rural population in Binyang County. The study was conducted in two villages (A and $\mathrm{B}$ ) from two towns (village $\mathrm{A}$ from town $\mathrm{C} 1$, and village $B$ from town $C 2$ ) selected at random. A total of 400 individuals were involved in our study. All participants were grouped according to gender, age, education level, and so on. Males accounted for 48.8\% (195/400) and females $51.2 \%(205 / 400)$ of participants. The average age was $35.7 \pm 25.3$, ranging from 7 months to 89 years old.

Table 1 Basic information on participants and assessment of risk factors for Cryptosporidium infection

\begin{tabular}{|c|c|c|c|}
\hline Variable & No. Examined (\%) & No. Positive & $p$-value \\
\hline \multicolumn{4}{|l|}{ Gender } \\
\hline Male & $195(48.8)$ & 2 & \multirow[t]{2}{*}{0.237} \\
\hline Female & $205(51.2)$ & 0 & \\
\hline \multicolumn{4}{|l|}{ Age } \\
\hline$<5$ years (infants) & $61(15.3)$ & 1 & \multirow[t]{5}{*}{0.502} \\
\hline 5-12 years (children) & $76(19.0)$ & 0 & \\
\hline 13-19 years (youths) & $11(2.7)$ & 0 & \\
\hline 20-49 years (adults) & $91(22.7)$ & 0 & \\
\hline 50 years up (elderly) & $161(40.3)$ & 1 & \\
\hline \multicolumn{4}{|l|}{ Education level } \\
\hline Primary and below & $227(56.8)$ & 2 & \multirow[t]{3}{*}{0.590} \\
\hline Junior middle school & $144(36.0)$ & 0 & \\
\hline High school and above & $29(7.2)$ & 0 & \\
\hline \multicolumn{4}{|l|}{ Drinking water sources } \\
\hline Tap water & $222(55.5)$ & 0 & \multirow[t]{3}{*}{0.203} \\
\hline Well or spring water & $176(44.0)$ & 2 & \\
\hline Others & $2(0.5)$ & 0 & \\
\hline \multicolumn{4}{|l|}{ Drinking unboiled water } \\
\hline Yes & $159(39.8)$ & 2 & \multirow[t]{2}{*}{0.157} \\
\hline No & $241(60.2)$ & 0 & \\
\hline \multicolumn{4}{|l|}{ Washing hands before meals } \\
\hline Yes & $347(86.8)$ & 2 & \multirow[t]{2}{*}{1.000} \\
\hline No & $53(13.2)$ & 0 & \\
\hline \multicolumn{4}{|c|}{ Eating unwashed vegetables and fruits } \\
\hline Yes & $179(44.8)$ & 2 & \multirow[t]{2}{*}{0.200} \\
\hline No & $221(55.2)$ & 0 & \\
\hline \multicolumn{4}{|l|}{ Animals raising } \\
\hline Yes & $261(65.3)$ & 2 & \multirow[t]{2}{*}{0.545} \\
\hline No & 139(34.7) & 0 & \\
\hline \multicolumn{4}{|l|}{ Diarrhea } \\
\hline Yes & $10(2.5)$ & 0 & \multirow[t]{2}{*}{1.000} \\
\hline No & $390(97.5)$ & 2 & \\
\hline
\end{tabular}


Participants with primary school education and below accounted for $56.8 \%$ (227/400), followed by junior high school level $(36.0 \% ; 144 / 400)$, and high school education and above (7.2\%; 29/400); 65.3\% (261/400) of participants reported raising animals at home. Basic information on all participants is shown in Table 1.

\section{Sample collection and questionnaire}

From August to December 2016, 400 fresh fecal samples $(>5 \mathrm{~g}$ ) were collected from villagers in the two selected villages. Samples were taken from the middle of the stool to avoid contamination from soil, animal manure or other human feces, and transported to the laboratory of the local Center for Disease Control within $4 \mathrm{~h}$ of collection. Samples were mixed with $2.5 \%$ potassium dichromate and stored in a refrigerator at $4{ }^{\circ} \mathrm{C}$. All samples were eventually sent to the laboratory of the National Institute of Parasitic Diseases, Center for Disease Control and Prevention of China. During sampling, villagers involved in the survey were presented with a structured questionnaire to collect data on sociodemographic factors (gender, age, education level), and possible risk factors (drinking and eating habits, hygiene habits, animals raising), as well as common clinical symptoms (diarrhea).

\section{DNA extraction}

Fecal samples (180-220 mg) were washed with deionized water and centrifuged at 20,000 g for $10 \mathrm{~min}$ three times to remove potassium dichromate, and DNA was extracted using a QIAamp DNA Stool Mini Kit (Qiagen, Hilden, Germany) following the manufacturer's instructions. To increase the DNA yield, the lysis temperature was adjusted to $95^{\circ} \mathrm{C}$ according to the manufacturer's recommendation. The final $200 \mu \mathrm{l}$ DNA samples were stored at $-30{ }^{\circ} \mathrm{C}$ for subsequent Polymerase Chain Reaction (PCR) analysis.

\section{PCR amplification and sequencing}

Nested PCR was used to identify Cryptosporidium species/genotype, initially by amplifying part of the smallsubunit rRNA (SSU rRNA) gene (approximately $840 \mathrm{bp}$ ) of Cryptosporidium using primer sets and cycling parameters described previously [22]. Primers used to amplify an $805-\mathrm{bp}$ fragment of the $60-\mathrm{kDa}$ glycoproteinencoding (gp60) gene of $C$. viatorum were described by Stensvold [23]. Heat shock protein 70 (hsp70) and actin genes of $C$. occultus were amplified using primers described by Sulaiman [24, 25] (see Additional file 1: Table S1).

All DNA samples were analyzed at least three times. A Cryptosporidium- positive DNA (cattle-derived C. andersoni) sample and nuclease-free water were used as positive and negative controls, respectively, and PCR products were analyzed by $2 \%$ agarose gel electrophoresis and ethidium bromide staining. Products of the expected size were analyzed using an ABI 3730 DNA Analyzer (Applied Biosystems, Foster City, USA) and Big Dye Terminator v3.1 Cycle Sequencing Kit (Applied Biosystems). ContigExpress software was used for sequence assembly and wave peak evaluation. Sequences were searched using the basic local alignment search tool (BLAST) and aligned with representative Cryptosporidium sequences.

\section{Phylogenetic analysis}

Phylogenetic trees were constructed using MEGA6.0 software [26] based on 1000 bootstrap replicates from sequences obtained in this study and representative Cryptosporidium sequences downloaded from the NCBI database. The subtype of $C$. viatorum was designated using the subtype naming guidelines [24].

\section{Statistical analysis}

SPSS 16.0 software was used for statistical analyses. Fisher's exact test were performed to compare infection rates between groups. Differences were regarded as statistically significant when $P<0.05$.

\section{Results}

\section{The prevalence of and risk factors for Cryptosporidium} infection

The prevalence of Cryptosporidium was 0.5\% (2/400). All 400 participants completed the questionnaire effectively. In the present study, several factors were analyzed. Univariate analysis of risk factors for Cryptosporidium are summarized in Table 1 . No statistical association was found between these factors and Cryptosporidium infection.

Both infected individuals were males from two villages. The person infected with C. viatorum was a 60-year-old man with gastric cancer who raised dogs. The other, infected with $C$. occultus, was a child younger than 5 years

Table 2 Characteristics of the two Cryptosporidium infection cases identified in Guangxi, China

\begin{tabular}{lll}
\hline Characteristics & Case 1 & Case 2 \\
\hline Gender & Male & Male \\
Age & 60 & 4 \\
Education level & Primary school & Below primary school \\
Drinking water source & Spring water & Well water \\
Drinking unboiled water & Yes & Yes \\
Animals raising & Yes (dogs) & Yes (dogs and chickens) \\
Contact with animals & Yes & Yes \\
Diarrhea & No & No \\
Nutritional status & Poor & General \\
Other diseases & Yes (gastric cancer) & No \\
Sampling time & August & December \\
\hline
\end{tabular}


old who often drank unboiled water, and dogs and chickens were raised in his home (Table 2). Both Cryptosporidium-infected individuals failed to display gastrointestinal symptoms.

\section{Genotype of Cryptosporidium spp}

Two samples were identified as Cryptosporidium-positive, and they corresponded to C. viatorum and C. occultus respectively, based on the SSU rRNA gene sequences. The gp60 gene of C. viatorum and actin and hsp70 genes of $C$. occultus were also successfully amplified. A novel subtype of C. viatorum was found and named XVaA3h.

Cryptosporidium sequences identified in the present study were submitted to GenBank under accession numbers MH807495 (C. viatorum SSU rRNA gene), MH807494 (C. viatorum gp60 gene), MH807493 (C. occultus SSU rRNA gene), MN177696 (C. occultus actin gene) and MN177697 (C. occultus hsp70 gene),

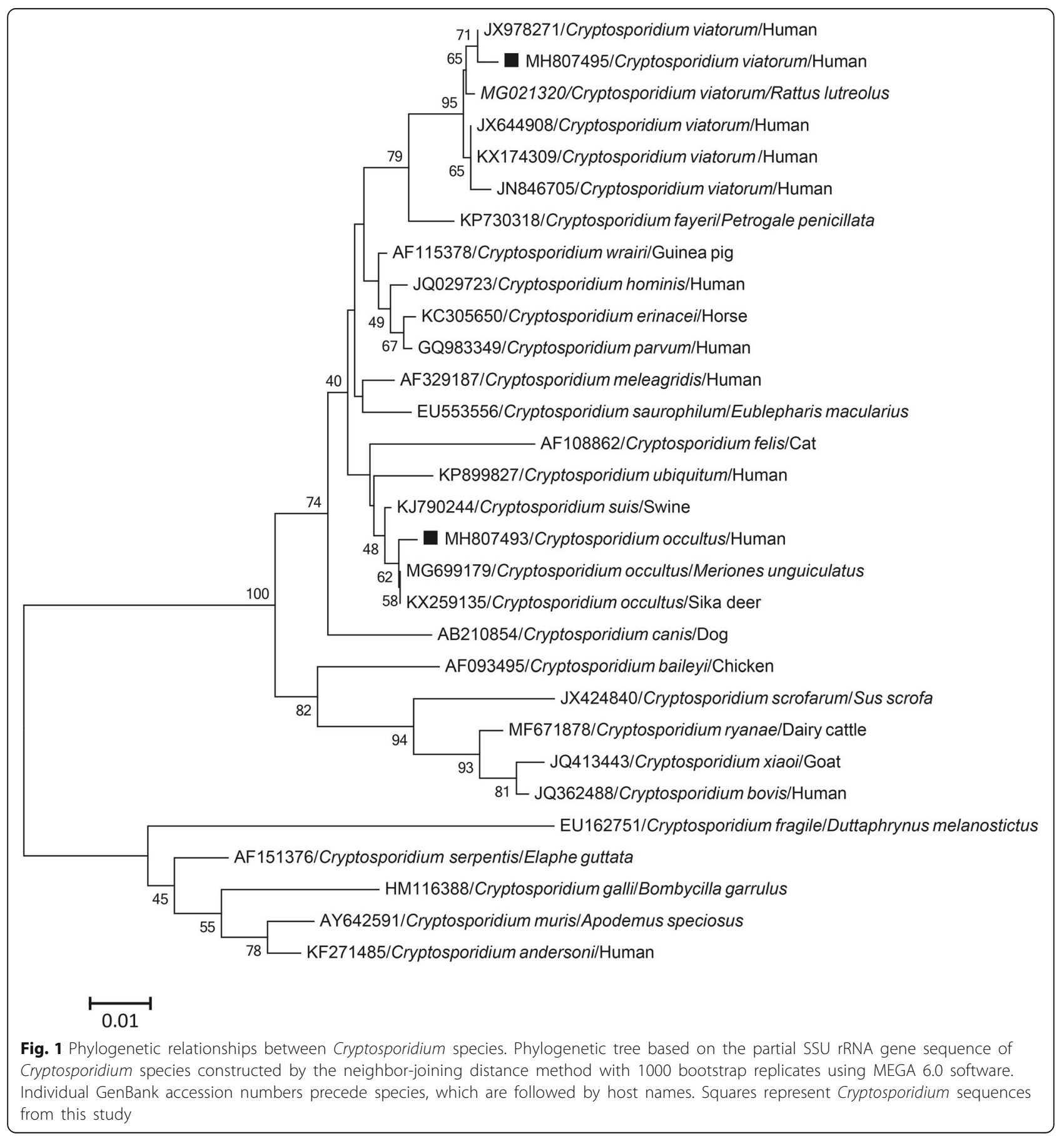




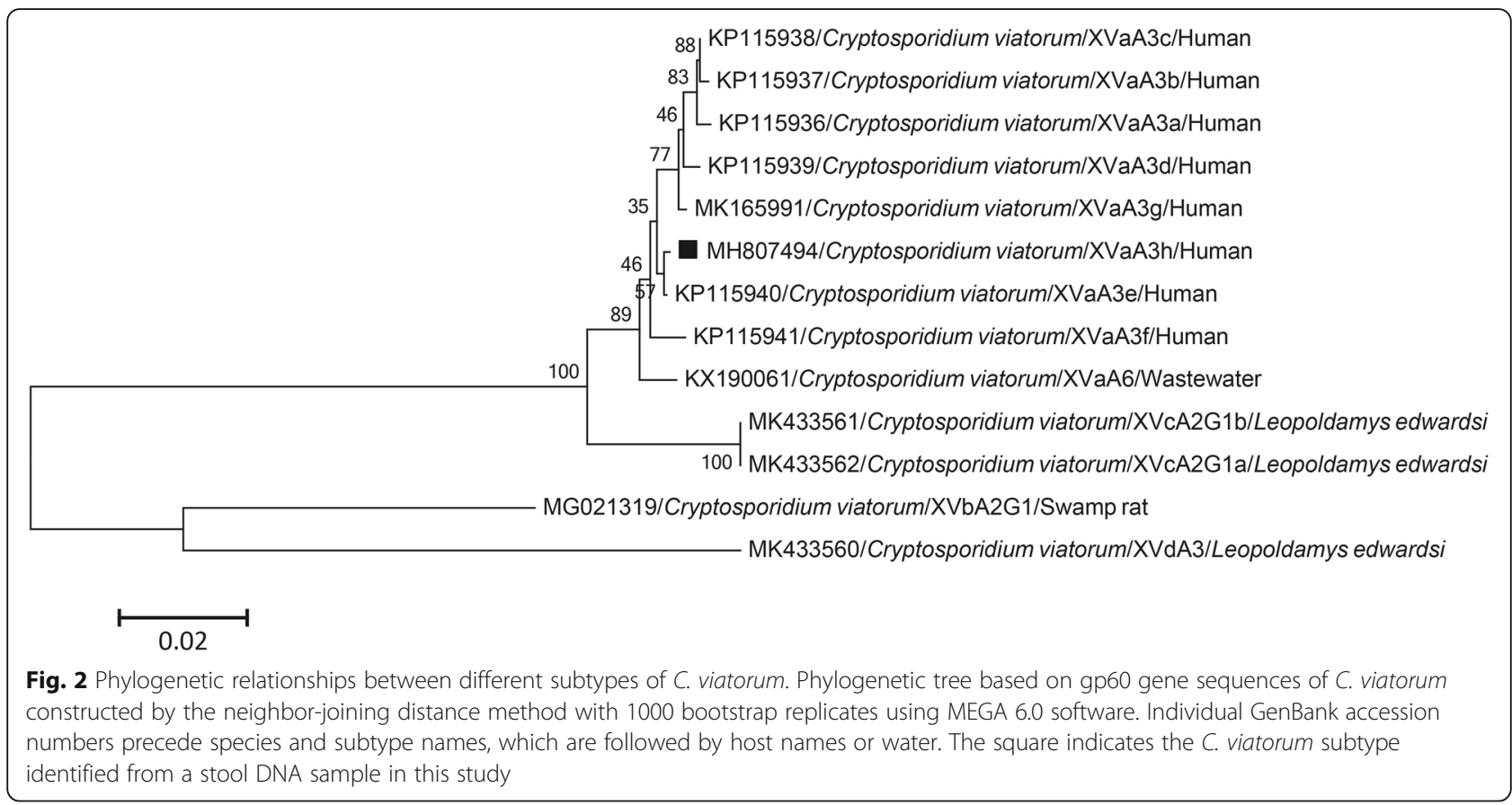

\section{Phylogenetic analysis of $C$. viatorum and $C$. occultus}

Phylogenetic analysis based on SSU rRNA gene sequences confirmed that one sample belonged to $C$. viatorum, and it was closely related to an isolate identified previously in a human in Kenya (accession no. JX978271) (Fig. 1), with one genetic variation. Sequence analysis based on the gp60 gene revealed three contiguous TCA trinucleotides in the serine repeat region, and two genetic variations in the non-repetitive region compared with an isolate from Nepal (accession no. KP115940). The sequence was designated XVaA3h (accession no. MH807494) (Fig. 2).

The other positive sample clustered with $C$. occultus sequences isolated from deer in China (accession no. KX259135) and Meriones unguiculatus in the Czech Republic (accession nos. MG699171 and MG699175) based on SSU rRNA, actin and hsp70 gene sequences, with which it shares $>99 \%$ sequence identity (Figs. 1 and 3).

\section{Discussion}

Traditionally, the identification of Cryptosporidium mainly depends on microscopy, which is time-consuming and experience-requiring, and this method is not applicable in the case of mild infection [27]. Compared with traditional morphological methods, molecular techniques are more sensitive for detection of Cryptosporidium in feces [17]. Nested PCR has been widely used in the detection of Cryptosporidium. Molecular epidemiology study on Cryptosporidium has been conducted in several provinces/ cities/autonomous regions of China, including Guangxi, Guangdong, Henan, Hubei, Jiangsu, Shanghai, Xinjiang and Yunnan, with the prevalence ranging from 0.0 to
$16.5 \%[7,8,10-12,17,18,28-30]$ (Table 3). In the present study, two Cryptosporidium-positive samples were detected based on the SSU rRNA gene, revealing a prevalence of $0.5 \%$, which is lower than that reported previously for a rural population in southwest China (12.6\%) and diarrhea patients in Jiangsu (9.9\%) and Shanghai (13.5\%) $[17,18,31]$. Comparing with the prevalence of Cryptosporidium in humans in other countries, this is lower than that reported for children in Egypt (1.4\%), Cambodia (7.7\%), and rural Ghana (5.2\%) and diarrhea patients in Canada (15.7\%) [32-35], but higher than that reported in a population-based laboratory surveillance in a large Canadian health region $(\sim 6.0$ per 100,000 members of the population per year) [36]. The prevalence of Cryptosporidium varies from country to country, and even within different areas in the same region, which may be related to the immune status, living environment, and even sampling time of the selected subjects.

Cryptosporidium is a common opportunistic pathogen in immunodeficient/immunocompromised individuals, especially HIV-infected patients, cancer patients and children younger than 5 years old $[10,29,37]$. In the present study, one case was a cancer patient and another was a child younger than 5 years old, both of whom were susceptible to Cryptosporidium. Age is one of the most important factors for cryptosporidiosis [7, 11], but no statistical association was observed in our present study, which could be mostly attributed to the population groups. Indeed, a previous study conducted in an underdeveloped rural community of southwest China found no association between infection and age groups [38] . 

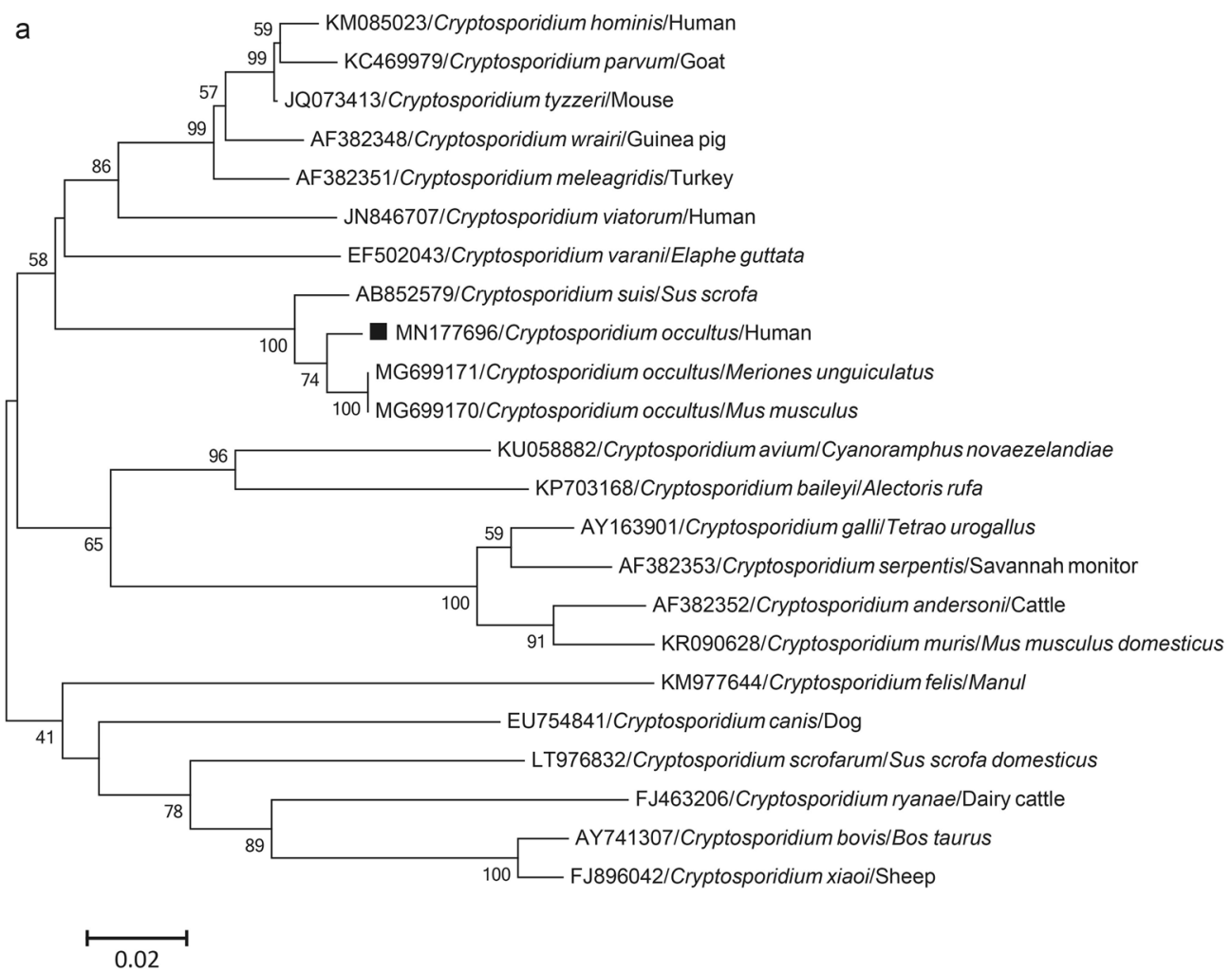

b

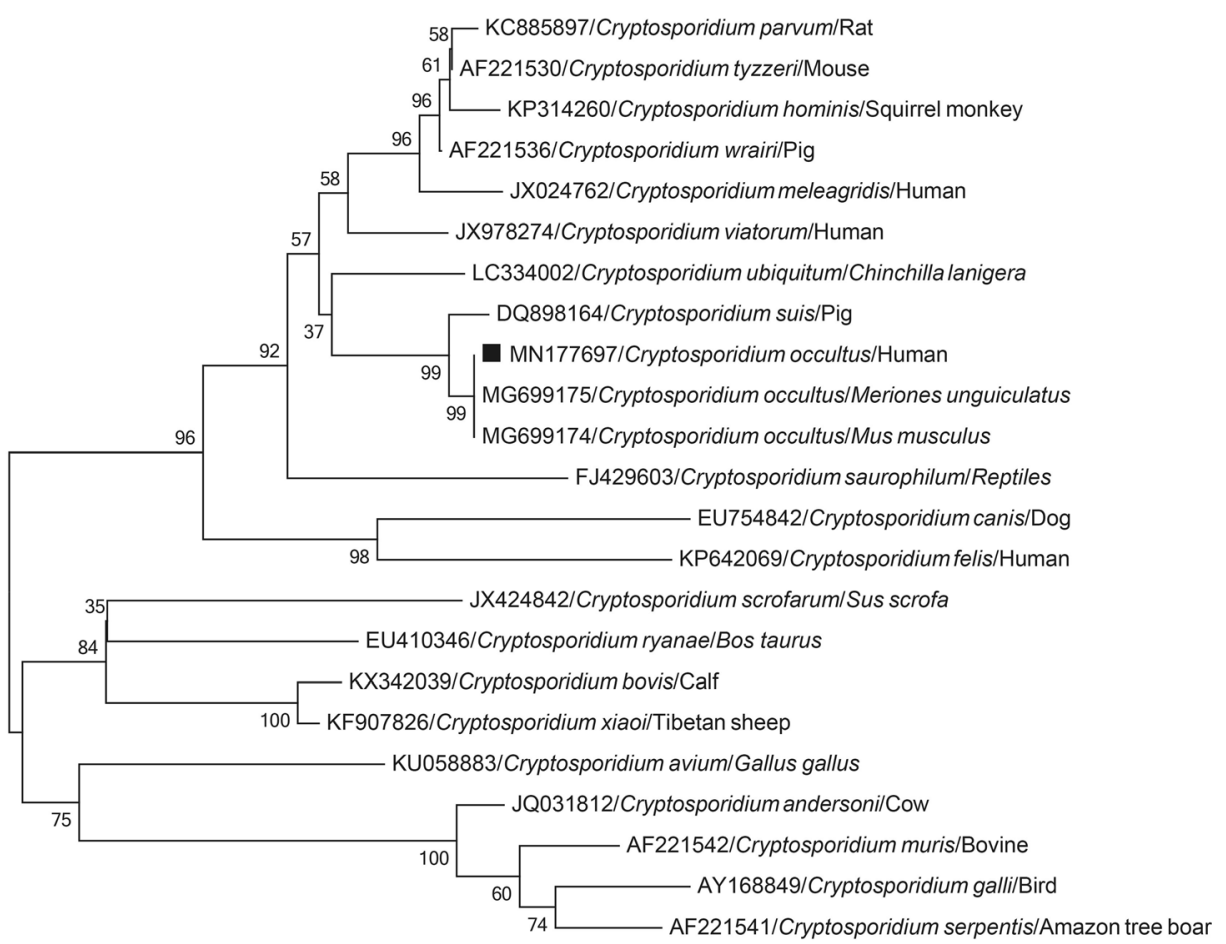

$\stackrel{\longmapsto}{0.02}$

Fig. 3 (See legend on next page.) 
(See figure on previous page.)

Fig. 3 Phylogenetic relationships between different species of Cryptosporidium based on actin gene (a) and heat shock protein 70 (hsp70) gene (b) sequences. The phylogenetic tree was constructed by the neighbor-joining distance method with 1000 bootstrap replicates using MEGA 6.0 software. Individual GenBank accession numbers precede species names, which are followed by host names. The square indicates C. occultus identified from a stool DNA sample in this study

Diarrhea is the most common clinical symptom associated with Cryptosporidium infection, and a statistically significant association between Cryptosporidium infection and diarrhea has been reported previously [39]. However, no statistical association was observed between Cryptosporidium infection and diarrhea in the present study $(p=1.000)$ which could be attributed to the species or subtypes of Cryptosporidium. The relationship between diarrhea and these two Cryptosporidium species (C. viatorum and C. occultus) remains unclear due to the lack of cases.

Cryptosporidium is a waterborne parasite and listed as one of the indispensable indicators of water quality according to the Hygienic Standards for Drinking Water in China (GB 5479-2006). However, in this study, statistically significant difference was not observed between individuals drinking unboiled water or not, which is contrary to the results of a study conducted in Russia [40]. The reason may be that people drinking boiled water in the present study accounted for 60.2\% (241/
400) of all the respondents. Although Cryptosporidium oocysts are resistant to low temperature and chlorine disinfectant in the external environment, heating at 65$70{ }^{\circ} \mathrm{C}$ for $30 \mathrm{~min}$ can kill Cryptosporidium oocysts. Some other factors (e.g. gender, education level, drinking water source, washing hands before meals, eating unwashed vegetables and fruits, and raising animals) were also analyzed, but no statistical correlation was found between those factors and Cryptosporidium infection.

Globally, C. hominis and C. parvum are the most common species causing cryptosporidiosis in humans, accounting for $>90 \%$ of cases [41]. Seven species of Cryptosporidium have been identified in humans in China with C. hominis and C. parvum being the commonest, but the distribution of Cryptosporidium species in China varies by region; $C$. hominis is mainly present in the east, while C. parvum is mainly found in the south-central region (Hunan Province) [42-44]. In the present study, C. viatorum and C. occultus were identified for the first time in humans in China.

Table 3 Species, positive rate, and risk factors associated with Cryptosporidium infection in humans in China

\begin{tabular}{|c|c|c|c|c|c|}
\hline Location & $\begin{array}{l}\text { Positive no./Examined } \\
\text { no. (\%) }\end{array}$ & Species (no.) & Population & Risk factor & References \\
\hline Guangxi & $6 / 258(2.3)$ & $\begin{array}{l}\text { C. andersoni (4) } \\
\text { C. hominis (2) }\end{array}$ & HIV-positive & No analysis & [28] \\
\hline Guangxi & $\begin{array}{l}2 / 285(0.7) \\
0 / 150\end{array}$ & $\begin{array}{l}\text { C. andersoni (1), } \\
\text { C. hominis (1) }\end{array}$ & $\begin{array}{l}\text { HIV-positive } \\
\text { HIV-negative }\end{array}$ & $\begin{array}{l}\text { HIV-positive with diarrhea } \\
\text { Location (Guilin) }\end{array}$ & [8] \\
\hline Guangdong & $12 / 348(3.5)$ & $\begin{array}{l}\text { C. hominis (8) } \\
\text { C. parvum (4) }\end{array}$ & Diarrheal children & No risk factor & [29] \\
\hline Henan & $\begin{array}{l}10 / 673(1.5) \\
1 / 628(0.2)\end{array}$ & $\begin{array}{l}\text { C. meleagridis (5), } \\
\text { C. hominis (3) } \\
\text { C. parvum (2) } \\
\text { C. suis (1) }\end{array}$ & HIV-positive HIV-negative & $\begin{array}{l}\text { HIV infection, Raising } \\
\text { sheep/goat } \\
\text { Well water as water source }\end{array}$ & [10] \\
\hline Hubei & 9/298 (3.0) & $\begin{array}{l}\text { C. parvum (9) } \\
\text { C. hominis ( } 2 \text { ) } \\
\text { two with mixed species }\end{array}$ & Diarrheal infants $<2$ years old & $\begin{array}{l}\text { Children with diarrhea } \\
\text { aged } 1-2\end{array}$ & [7] \\
\hline Jiangsu & 23/232 (9.9) & $\begin{array}{l}\text { C. andersoni (21), } \\
\text { C. hominis (2), }\end{array}$ & Diarrheal outpatients & Autumn & [17] \\
\hline Shanghai & $34 / 252(13.5)$ & C. andersoni (34) & Diarrheal outpatients & Winter & [18] \\
\hline Shanghai & 102/6284 (1.6) & $\begin{array}{l}\text { C. hominis (92) } \\
\text { C. meleagridis (6) } \\
\text { C. canis (2) } \\
\text { C. felis (2) }\end{array}$ & Children in hospitals & $\begin{array}{l}\text { Children < } 6 \text { months, } \\
\text { February-July } 2008 \\
\text { Diarrhea }\end{array}$ & [11] \\
\hline Xinjiang & $38 / 230(16.5)$ & $\begin{array}{l}\text { C. hominis }(-) \\
\text { C. parvum (-) }\end{array}$ & Diarrheal patients & No analysis & [12] \\
\hline Yunnan & $\begin{array}{l}1 / 850(0.1) \\
0 / 170\end{array}$ & - & $\begin{array}{l}\text { Asymptomatic and diarrheic } \\
\text { children }\end{array}$ & No risk factor & [30] \\
\hline
\end{tabular}


C. viatorum, previously believed to be a human-specific pathogen, was first isolated from travelers returning to Britain from India in 2012 [45]. C. viatorum has since been identified in people from or who travelled to Bangladesh, Barbados, Colombia, Dubai, Ethiopia, Guatemala, India, Kenya, Nepal, Nigeria, Pakistan and Australia [20, 23, 45-53]. Recently, researchers in Australia and China identified C. viatorum in rats, underlining its zoonotic potential $[54,55]$. It was also identified in untreated water in China [56]. In the present study, we identified the subtype XVaA3h of $C$. viatorum in a human for the first time (Table 4).

Based on the gp60 gene sequence, which is applied in subtype analysis of several pathogenic Cryptosporidium species, including C. hominis, C. parvum, C. ubiquitum, $C$. meleagridis, C. viatorum, Cryptosporidium skunk genotype and Cryptosporidium chipmunk genotype I [56], C. viatorum has evolved into 13 subtypes, named XVaA3a-h, XVaA6, XVbA2G1, XVcA2G1a, XVcA2G1b and XVdA3. The sequence of the gp60 gene of XVaA3h identified in our study shares $>98 \%$ identity with other $C$. viatorum subtypes, isolated from humans in Nepal (accession no. KP115940), Guatemala (accession no. KP115938), India (accession nos. KP115941 and KP115936) and Kenya (accession no. KP115939), and is 97\% identical to an isolate from waste water in China (accession no. KX190061). High genetic identity among $C$. viatorum subtypes XVaA3a-h may suggest that $C$. viatorum recently spread from the source population and is now spreading further through global human travel [54]. However, no travel history was reported in our study. Perhaps animals or contaminated water contribute to the infection, considering the fact that $C$. viatorum has been identified in animals and water [54-56].

C. occultus, named by Martin Kvác in 2018 [15], and was previously known as Cryptosporidium suis-like, due to the close phylogenetic relationship with C. suis. However, oocysts of $C$. occultus are morphologically indistinguishable from other species/genotypes, while oocysts of C. occultus are smaller than those of C. suis [15]. Previous phylogenetic analyses based on SSU rRNA, actin, and hsp70 genes revealed $0.3,2.0$, and $2.1 \%$ sequence divergence from $C$. suis, respectively, hence $C$. occultus and $C$. suis can be distinguished genetically [15].

Although C. occultus has a wide host range (cattle, yak, water buffalo, and rat), one study showed that rats are the main host [15]. To date, only two cases of humans infected with $C$. occultus have been reported, in Canada and in England [57, 58]. C. occultus has been detected in cattle, yak, and wild rats in China $[55,59,60]$. Our present study is the first report of C. occultus in a human in China. However, the transmission route is not clear due to limited detection of $C$. occultus in animals and humans.

Various zoonotic Cryptosporidium species (C. hominis, C. parvum, C. meleagridis, C. andersoni, C. felis, C. ubiquitum, Cryptosporidium horse genotype, $C$. suis and $C$.

Table 4 C. viatorum identified in humans, animals, and water samples worldwide

\begin{tabular}{|c|c|c|c|c|c|}
\hline Country & Host & Year & Travel history & Subtype & References \\
\hline UK & Human & $\begin{array}{l}2012 \\
2015\end{array}$ & $\begin{array}{l}\text { Yes } \\
\text { Bangladesh (1) } \\
\text { India (9) } \\
\text { Nepal (1) } \\
\text { Pakistan (1) } \\
\text { Unknown (2) }\end{array}$ & $\begin{array}{l}\text { XVaA3a (9) } \\
\text { XVaA3d (2) } \\
\text { XVaA3e (1) } \\
\text { XVaA3f (2) }\end{array}$ & {$[23,45]$} \\
\hline Sweden & Human & 2013 & $\begin{array}{l}\text { Yes } \\
\text { Kenya (2) } \\
\text { Guatemala (1) }\end{array}$ & $\begin{array}{l}\text { XVaA3b (1) } \\
\text { XVaA3c (1) } \\
\text { XVaA3d (1) }\end{array}$ & {$[23,46,47]$} \\
\hline Ethiopia & Human & $\begin{array}{l}2014 \\
2015 \\
2016\end{array}$ & Unknown (22) & $\begin{array}{l}\text { XVaA3d (9) } \\
\text { Unknown (13) }\end{array}$ & {$[20,23,48]$} \\
\hline Nigeria & Human & $\begin{array}{l}2014 \\
2017\end{array}$ & Unknown (2) & Unknown (2) & {$[49,50]$} \\
\hline Colombia & Human & 2017 & Unknown (1) & Unknown (1) & [51] \\
\hline China & Waste water & 2017 & - & XVaA6 & {$[56]$} \\
\hline India & Human & 2018 & Unknown (1) & Unknown (1) & {$[52]$} \\
\hline Australia & Rat & 2018 & - & $\begin{array}{l}\text { XVbA2G1 (1) } \\
\text { Unknown (2) }\end{array}$ & [54] \\
\hline Australia & Human & 2019 & Unknown (1) & XVaA3g (1) & [53] \\
\hline China & Leopoldamys edwardsi & 2019 & - & $\begin{array}{l}\text { XVcA2G1a (4) } \\
\text { XVcA2G1b (1) } \\
\text { XVdA3 (1) }\end{array}$ & {$[55]$} \\
\hline China & Human & 2019 & No (1) & XVaA3h (1) & This study \\
\hline
\end{tabular}


viatorum) have been found in different water bodies that may be contaminated by animal and human feces, indicating a transmission cycle of Cryptosporidium among humans, animals and water $[1,61]$. Study also suggested that water may be contaminated with C. occultus [15]. To better understand the transmission dynamics of cryptosporidiosis and provide targeted preventive measures, further molecular investigations of Cryptosporidium in animal and water samples are required.

\section{Conclusions}

The present study identified C. viatorum and C. occultus in humans in China for the first time, and also documents the novel $C$. viatorum subtype XVaA3h, expanding the known range of Cryptosporidium species infecting humans worldwide. Those two Cryptosporidium species have both been identified in animals, suggesting the possibility of zoonotic transmission of Cryptosporidium in this locale. Further systematic molecular investigation of Cryptosporidium should focus on humans, animals and water samples to clarify the transmission routes.

\section{Supplementary information}

Supplementary information accompanies this paper at https://doi.org/10. 1186/s12879-019-4693-9.

Additional file 1: Table S1. Primers used in the study.

\section{Abbreviations}

HIV/AIDS: Human Immunodeficiency Virus/Acquired Immune Deficiency Syndrome; SSU rRNA: small subunit RNA; gp60: 60-kDa glycoproteinencoding; hsp70: heat shock protein 70

\section{Acknowledgements}

The authors are grateful to the staff at the Department of Parasitic Diseases Prevention and Control, Binyang County Centre for Disease Control and Prevention, Guangxi Zhuang Autonomous Region, and the Guangxi Zhuang Autonomous Region Centre for Disease Control and Prevention, for their assistance with sample collection and the questionnaire survey.

\section{Authors' contributions}

YS and JC conceptualized and designed the study. NX, HL, JY and ZY performed the experiments. NX, YJ, YS and JC analyzed the data. YS and JC contributed reagents/materials/analysis tools. NX wrote the manuscript. YS and $\mathrm{JC}$ revised the manuscript and performed the final revision. All authors read and approved the final manuscript.

\section{Funding}

This study was supported by the Chinese Special Program for Scientific Research of Public Health (grant no. 201502021 to JC), the National Science and Technology Major Program of China (grant no. 2018ZX10713001-004 to YS and 2018ZX10201002-009 to JY), the National Natural Science Foundation of China (grant no. 81772225 to JC), and the Fourth Round of Three-Year Public Health Action Plan of Shanghai, China (grant no. 15GWZK0101 to JC). The funders had no role in study design, data collection and analysis, decision to publish, or preparation of the manuscript.

\section{Availability of data and materials}

The datasets generated and/or analysed during the current study are not publicly available in order to protect participant confidentiality. The gene sequences from Cryptosporidium identified in this study were submitted to
GenBank with accession numbers MH807493-MH807495 and MN177696MN177697.

Ethics approval and consent to participate

The study was approved by the Ethics Committee of the National Institute of Parasitic Diseases, Chinese Center for Disease Control and Prevention (No. 2014-001). All participants were informed of the objectives, procedures, and potential risks of the study. Written informed consent was personally signed by all adult subjects. Parents or guardians were asked to provide written consent on behalf of child participants. The personal information of all participants has remained confidential.

\section{Consent for publication}

Not applicable.

\section{Competing interests}

The authors declare that they have no competing interests.

\section{Author details}

${ }^{1}$ Key Laboratory of Parasite and Vector Biology, Ministry of Health, Shanghai 200025, China. ${ }^{2}$ National Institute of Parasitic Diseases, Chinese Center for Disease Control and Prevention, Shanghai 200025, China. ${ }^{3}$ Chinese Center for Tropical Diseases Research, Shanghai 200025, China. ${ }^{4}$ WHO Collaborating Centre for Tropical Diseases, Shanghai 200025, China. ${ }^{5}$ National Center for International Research on Tropical Diseases, Ministry of Science and Technology, Shanghai 200025, China.

Received: 12 May 2019 Accepted: 9 December 2019

Published online: 07 January 2020

References

1. Feng Y, Xiao L. Molecular epidemiology of cryptosporidiosis in China. Front Microbiol. 2017:8:1701.

2. Mac Kenzie WR, Hoxie NJ, Proctor ME, Gradus MS, Blair KA, Peterson DE, et al. A massive outbreak in Milwaukee of Cryptosporidium infection transmitted through the public water supply. N Engl J Med. 1994;331:161-7.

3. Vanathy K, Parija SC, Mandal J, Hamide A, Krishnamurthy S. Cryptosporidiosis: A mini review. Trop Parasitol. 2017;7:72-80.

4. McKerr C, Adak GK, Nichols G, Gorton R, Chalmers RM, Kafatos G, et al. An outbreak of Cryptosporidium parvum across England \& Scotland Associated with consumption of fresh pre-cut salad leaves, may 2012. PLoS One. 2015; 10:e0125955.

5. Sow SO, Muhsen K, Nasrin D, Blackwelder WC, Wu Y, Farag TH, et al. The burden of Cryptosporidium diarrheal disease among children $<24$ months of age in moderate/high mortality regions of sub-saharan africa and south asia, utilizing data from the global enteric multicenter study (GEMS). PLOS Negl Trop Dis. 2016;10:e0004729.

6. Yang D, Yang Y, Wang Y, Yang Y, Dong S, Chen Y, et al. Prevalence and risk factors of Ascaris lumbricoides, Trichuris trichiura and Cryptosporidium infections in elementary school children in southwestern China: a schoolbased cross-sectional study. Int J Environ Res Public Health. 2018;15:E1809.

7. Xiaojie L, Mao T, Wu P, Rui Z. Molecular epidemiology of Cryptosporidium infection in infants with diarrhea in Wuhan City. Chin J Schisto Control. 2017;29:188-91 205 (In Chinese).

8. Wang Z, Zhihua J, Yu B, Dongsheng Z, Lin Y, Wengian T. Preliminary study on infection status and gene types of Cryptosporidium among HIV/AIDS patients in Guangxi. Chin J Schisto Control. 2016:28:550-3 (In Chinese).

9. Lv S, Tian LG, Liu Q, Qian MB, Fu Q, Steinmann P, et al. Water-related parasitic diseases in China. Int J Environ Res Public Health. 2013;10:19772016

10. Wang L, Zhang H, Zhao X, Zhang L, Zhang G, Guo M, et al. Zoonotic Cryptosporidium species and enterocytozoon bieneusi genotypes in HIVpositive patients on antiretroviral therapy. J Clin Microbiol. 2013;51:557-63.

11. Feng $Y$, Wang L, Duan L, Gomez-Puerta LA, Zhang L, Zhao $X$, et al. Extended outbreak of cryptosporidiosis in a pediatric hospital, China. Emerg Infect Dis. 2012;18:312-4

12. Bing Z, Yuanzhou Z, Xiaojing Z. Wang xiao. Identification of Cryptosporidium species from fecal samples of one hospital in Xinjiang. Progress Vet Med. 2017;38:53-6 (In Chinese). 
13. Zahedi A, Monis P, Gofton AW, Oskam CL, Ball A, Bath A, et al. Cryptosporidium species and subtypes in animals inhabiting drinking water catchments in three states across Australia. Water Res. 2018;134:327-40.

14. Čondlová Š, Horčičková M, Sak B, Květoňová D, Hlásková L, Konečný R, et al. Cryptosporidium apodemi sp. n. and Cryptosporidium ditrichi sp. n. (Apicomplexa: Cryptosporidiidae) in Apodemus spp. Eur J Protistol. 2018;63: $1-12$.

15. Kváč $M$, VInatá $G$, Ježková J, Horčičková $M$, Konečný $R$, Hlásková L, et al. Cryptosporidium occultus sp. n. (Apicomplexa: Cryptosporidiidae) in rats. Eur J Protistol. 2018;63:96-104

16. Holubová N, Zikmundová V, Limpouchová Z, Sak B, Konečný R, Hlásková L. Cryptosporidium proventriculi sp. n. (Apicomplexa: Cryptosporidiidae) in Psittaciformes birds. Eur J Protistol. 2019;69:70-87.

17. Jiang Y, Ren J, Yuan Z, Liu A, Zhao H, Liu H, et al. Cryptosporidium andersoni as a novel predominant Cryptosporidium species in outpatients with diarrhea in Jiangsu Province, China. BMC Infect Dis. 2014;14:555.

18. Liu H, Shen Y, Yin J, Yuan Z, Jiang Y, Xu Y, et al. Prevalence and genetic characterization of Cryptosporidium, Enterocytozoon, Giardia and Cyclospora in diarrheal outpatients in China. BMC Infect Dis. 2014;14:25.

19. Chalmers RM, Robinson G, Elwin K, Hadfield SJ, Xiao L, Ryan U, et al. Cryptosporidium sp. rabbit genotype, a newly identified human pathogen. Emerg Infect Dis. 2009;15:829-30.

20. Adamu H, Petros B, Zhang G, Kassa H, Amer S, Ye J, et al. Distribution and clinical manifestations of Cryptosporidium species and subtypes in HIV/AIDS patients in Ethiopia. PLoS Negl Trop Dis. 2014;8:e2831.

21. Zheng H, He J, Wang L, Zhang R, Ding Z, Hu W. Risk factors and spatial clusters of Cryptosporidium infection among school-age children in a rural region of eastern China. Int J Environ Res Public Health. 2018;15:E924.

22. Yin J, Yuan Z, Shen Y, Zhang J, Jiang Y, Cao J. Molecular identification of Cryptosporidium spp. from animal sources in China [letter]. J Infect Dev Ctries. 2013;7:1020-2.

23. Stensvold CR, Elwin K, Winiecka-Krusnell J, Chalmers RM, Xiao L, Lebbad M. Development and application of a gp60-based typing assay for Cryptosporidium viatorum. J Clin Microbiol. 2015;53:1891-7.

24. Sulaiman IM, Morgan UM, Thompson RC, Lal AA, Xiao L. Phylogenetic relationships of Cryptosporidium parasites based on the 70-Kilodalton heat shock protein (hsp70) gene. Appl Environ Microbiol. 2000;66:2385-91.

25. Sulaiman IM, Lal AA, Xiao L. Molecular phylogeny and evolutionary relationships of Cryptosporidium parasites at the actin locus. J Parasitol. 2002; 88:388-94.

26. Tamura K, Stecher G, Peterson D, Filipski A, Kumar S. MEGA6: molecular evolutionary genetics analysis version 6.0. Mol Biol Evol. 2013:30:2725-9.

27. Weber R, Bryan RT, Bishop HS, Wahlquist SP, Sullivan JJ, Juranek DD. Threshold of detection of Cryptosporidium oocysts in human stool specimens: evidence for low sensitivity of current diagnostic methods. J Clin Microbiol. 1991;29:1323-7.

28. Haiping $S$, Xingfeng $H$, Yongmin $Q$, Suxian $Q$, Zhongyuan $H$, Ningsheng $W$ et al. An investigation on the gene types of Cryptosporidium among HIV/ AIDS patients. J Med Pest Control. 2017;33:151-3 (In Chinese).

29. Yuexian Y, Huifang C, Xie L, Ni X, Yuan X, Yanhui H, et al. Molecular epidemiological studies of cryptosporidiosis diarrhea in children of Guangzhou sentinel hospital. J Trop Med. 2014;14:60-3 (In Chinese).

30. Zhang SX, Zhou YM, Xu W, Tian LG, Chen JX, Chen SH, et al. Impact of coinfections with enteric pathogens on children suffering from acute diarrhea in Southwest China. Infect Dis Poverty. 2016;5:64.

31. Yang $Y$, Zhou $Y$, Cheng W, Pan $X$, Xiao $P$, Shi $Y$, et al. Prevalence and determinants of Cryptosporidium infection in an underdeveloped rural region of southwestern China. Am J Trop Med Hyg. 2017;96:595-601.

32. Naguib D, El-Gohary AH, Roellig D, Mohamed AA, Arafat N, Wang Y, et al. Molecular characterization of Cryptosporidium spp and Giardia duodenalis in children in Egypt. Parasit Vectors. 2018;11:403.

33. Moore CE, Elwin K, Phot N, Seng C, Mao S, Suy K, et al. Molecular characterization of Cryptosporidium species and Giardia duodenalis from symptomatic Cambodian children. PLoS Negl Trop Dis. 2016;10:e0004822.

34. Iqbal A, Goldfarb DM, Slinger R, Dixon BR. Prevalence and molecular characterization of Cryptosporidium spp. and Giardia duodenalis in diarrhoeic patients in the Qikiqtani region, Nunavut, Canada. Int J Circumpolar Health. 2015;74:27713.

35. Eibach D, Krumkamp R, Al-Emran HM, Sarpong N, Hagen RM, Adu-Sarkodie $Y$, et al. Molecular characterization of Cryptosporidium spp among children in rural Ghana. PLoS Negl Trop Dis. 2015;9:e0003551.
36. Laupland KB, Church DL. Population-based laboratory surveillance for Giardia sp and Cryptosporidium sp infections in a large Canadian health region. BMC Infect Dis. 2005;5:72.

37. Sulżyc-Bielicka V, Kołodziejczyk L, Jaczewska S, Bielicki D, Safranow K, Bielicki P. Et al.Colorectal cancer and Cryptosporidium spp. infection. PLoS One. 2018;13:e0195834.

38. Yang Y, Zhou YB, Xiao PL, Shi Y, Chen Y, Liang S, et al. Prevalence of and risk factors associated with Cryptosporidium infection in an underdeveloped rural community of Southwest China. Infect Dis Poverty. 2017;6:2.

39. Kiani H, Haghighi A, Seyyedtabaei SJ, Azargashsb E, Zebardast N, Taghipour $\mathrm{N}$, et al. Prevalence, clinical manifestations and genotyping of Cryptosporidium spp. in patients with gastrointestinal illnesses in western Iran. Iran J Parasitol. 2017:12:169-76.

40. Egorov A, Frost F, Muller T, Naumova E, Tereschenko A, Ford T. Serological evidence of Cryptosporidium infections in a Russian city and evaluation of risk factors for infections. Ann Epidemiol. 2004;14:129-36.

41. Bouzid M, Hunter PR, Chalmers RM, Tyler KM. Cryptosporidium pathogenicity and virulence. Clin Microbiol Rev. 2013;26:115-34.

42. Wang R, Zhang X, Zhu H, Zhang L, Feng Y, Jian F, et al. Genetic characterizations of Cryptosporidium spp. and Giardia duodenalis in humans in Henan, China. Exp Parasitol. 2011;127:42-5.

43. Peng MM, Matos O, Gatei W, Das P, Stantic-Pavlinic M, Bern CA, et al. A comparison of Cryptosporidium subgenotypes from several geographic regions. J Eukaryot Microbiol. 2001;1(suppl):28s-31s.

44. Yu Z, Li F, Zeng Z, Huang Z, Fan Z, Jin Y, et al. Prevalence and clinical significance of Cryptosporidium infection in patients with hepatitis B virusassociated acute-on-chronic liver failure. Int J Infect Dis. 2011;15:e845-8.

45. Elwin K, Hadfield SJ, Robinson G, Crouch ND, Chalmers RM. Cryptosporidium viatorum n. sp. (Apicomplexa: Cryptosporidiidae) among travellers returning to Great Britain from the Indian subcontinent, 2007-2011. Int J Parasitol. 2012:42:675-82.

46. Insulander M, Silverlås C, Lebbad M, Karlsson L, Mattsson JG, Svenungsson B. Molecular epidemiology and clinical manifestations of human cryptosporidiosis in Sweden. Epidemiol Infect. 2013;141:1009-20.

47. Lebbad M, Beser J, Insulander M, Karlsson L, Mattsson JG, Svenungsson B, et al. Unusual cryptosporidiosis cases in Swedish patients: extended molecular characterization of Cryptosporidium viatorum and Cryptosporidium chipmunk genotype I. Parasitology. 2013;140:1735-40.

48. de Lucio A, Amor-Aramendía A, Bailo B, Saugar JM, Anegagrie M, Arroyo A, et al. Prevalence and genetic diversity of Giardia duodenalis and Cryptosporidium spp. among school children in a rural area of the Amhara region, north-West Ethiopia. PLoS One. 2016;11:e0159992.

49. Ayinmode AB, Zhang H, Dada-Adegbola HO, Xiao L. Cryptosporidium hominis subtypes and Enterocytozoon bieneusi genotypes in HIV-infected persons in Ibadan, Nigeria. Zoonoses Public Health. 2014;61:297-303.

50. Ukwah BN, Ezeonu IM, Ezeonu CT, Roellig D, Xiao L. Cryptosporidium species and subtypes in diarrheal children and HIV-infected persons in Ebonyi and Nsukka, Nigeria. J Infect Dev Ctries. 2017;11:173-9.

51. Sánchez A, Munoz M, Gómez N, Tabares J, Segura L, Salazar Á, et al. Molecular epidemiology of Giardia, Blastocystis and Cryptosporidium among indigenous children from the Colombian Amazon Basin. Front Microbiol. 2017:8:248.

52. Khalil S, Mirdha BR, Paul J, Panda A, Singh Y. Molecular detection and identification of Cryptosporidium viatorum in a human immunodeficiency virus-seropositive patient. J Global Infect Dis. 2018;10:28-9.

53. Braima K, Zahedi A, Oskam C, Reid S, Pingault N, Xiao L. Retrospective analysis of Cryptosporidium species in Western Australian human populations (2015-2018), and emergence of the C. hominis IfA12G1R5 subtype. Infect Genet Evol. 2019;73:306-13.

54. Koehler AV, Wang T, Haydon SR, Gasser RB. Cryptosporidium viatorum from the native Australian swamp rat Rattus lutreolus - an emerging zoonotic pathogen? Int J Parasitol Parasites Wildl. 2018;7:18-26.

55. Zhao W, Zhou H, Huang Y, Xu L, Rao L, Wang S, et al. Cryptosporidium spp. in wild rats (Rattus spp.) from the Hainan Province, China: molecular detection, species/genotype identification and implications for public health. IJP: Parasites Wildlife. 2019;9:317-21.

56. Xiao L, Feng Y. Molecular epidemiologic tools for waterborne pathogens Cryptosporidium spp. and Giardia duodenalis. Food Waterborne Parasitol. 2017:8-9:14-32.

57. Ong CS, Eisler DL, Alikhani A, Fung WW, Tomblin J, Bowie WR, et al. Novel Cryptosporidium genotypes in sporadic cryptosporidiosis cases: first report of human infections with a cervine genotype. Emerg Infect Dis. 2002;8:263-8. 
58. Robinson G, Chalmers RM, Stapleton C, Palmer SR, Watkins J, Francis C, et al. A whole water catchment approach to investigating the origin and distribution of Cryptosporidium species. J Appl Microbiol. 2011;111:717-30.

59. Ma J, Li P, Zhao X, Xu H, Wu W, Wang Y, et al. Occurrence and molecular characterization of Cryptosporidium spp. and Enterocytozoon bieneusi in dairy cattle, beef cattle and water buffaloes in China. Vet Parasitol. 2015;207:220-7.

60. Li P, Cai J, Cai M, Wu W, Li C, Lei M, et al. Distribution of Cryptosporidium species in Tibetan sheep and yaks in Qinghai, China. Vet Parasitol. 2016;215: 58-62.

61. Huang C, Hu Y, Wang L, Wang Y, Li N, Guo Y, et al. Environmental transport of emerging human-pathogenic Cryptosporidium species and subtypes through combined sewer overflow and wastewater. Appl Environ Microbiol. 2017;83:e00682-17.

\section{Publisher's Note}

Springer Nature remains neutral with regard to jurisdictional claims in published maps and institutional affiliations.

Ready to submit your research? Choose BMC and benefit from:

- fast, convenient online submission

- thorough peer review by experienced researchers in your field

- rapid publication on acceptance

- support for research data, including large and complex data types

- gold Open Access which fosters wider collaboration and increased citations

- maximum visibility for your research: over $100 \mathrm{M}$ website views per year

At $\mathrm{BMC}$, research is always in progress.

Learn more biomedcentral.com/submissions 